\title{
FOLKTALES OF MEANDASH, THE MYTHIC SAMI REINDEER
}

\section{Part 1}

\section{Enn Ernits}

Nearly 30 stories concerning the wild reindeer Meandash have been recorded from the Sami of the Kola Peninsula (see Table 1). One of these folktales, recorded on a 1873 field trip to the Kola Peninsula, was first published by the Russian author Vassili NemirovichDanchenko (Nemirovich-Danchenko 1877: 209; s.a.: 362). Whether the story concerned Meandash, is not known.

A Finnish linguist Arvid Genetz $(1878,1879$ a) made a trip to Kola in 1876 , and subsequently published a folktale about proposals of marriage made by a raven, a seal and a reindeer to the daughters of an old Sami man. The story is undoubtedly connected to Meandash (or in the author's version: 'Mientush' or 'Mintysh'). Genetz also published the same folktale in an Hungarian scientific journal (Genetz 1879b; see also 1891).

\begin{tabular}{l|ccccc}
$\begin{array}{l}\text { Collection } \\
\text { site }\end{array}$ & $\begin{array}{l}\text { Life on the } \\
\text { land of } \\
\text { forefathers }\end{array}$ & $\begin{array}{l}\text { Culture } \\
\text { hero }\end{array}$ & $\begin{array}{l}\text { The victim of } \\
\text { the thunder } \\
\text { deity }\end{array}$ & $\begin{array}{l}\text { Sun } \\
\text { deity }\end{array}$ & TOTAL \\
\hline Imandra & 4 & - & 1 & 1 & 6 \\
Kolta & 3 & 1 & 2 & - & 6 \\
Kildin & 5 & - & - & - & 5 \\
Turia & 7 & - & 1 & 1 & 9 \\
Unknown & 3 & - & - & - & 3 \\
TOTAL & 22 & 1 & 4 & 2 & 29
\end{tabular}

Table 1. The parts of Meandash stories relative to different versions and language groups.

Two of the stories narrated by the Sami were written down in 1887 by a local priest Konstantin Shchekoldin (Shchekoldin 1890), another tale was recorded by a naturalist A. Iashchenko, though the year of recording is unknown (Iashchenko 1892). The ethnogra- 


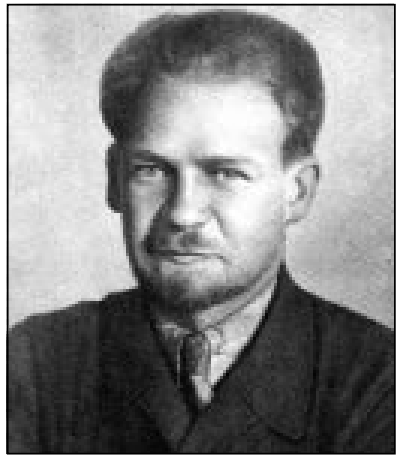

Photo 1. Vladimir

Charnoluski (1894-1969).

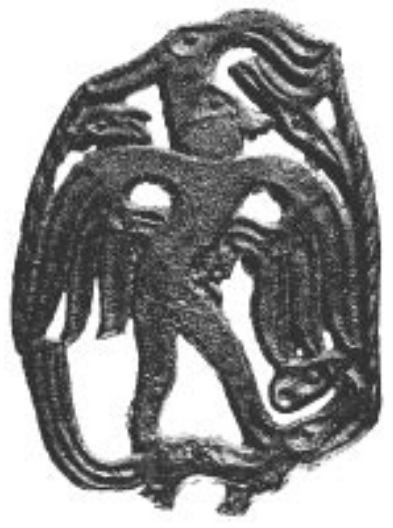

Figure 1. The Meandashstories have been used in interpreting the contents of the Perm animal-style brass fillets. A human reindeer with wings on a saurian creature. 7th-8th century. After Oborin \& Chagin 1988. pher Nikolai Haruzin has also taken interest in this tale, though to a smaller extent (Haruzin 1890).

The few Meandash stories recorded in the present century have been published by E. Itkonen 1931-1936, E. Itkonen 1985, Sienkiewicz-Gudkova 1960, Szabò 1967, Kert 1961, 1980, Kert \& Zaikov 1988. The largest number of Meandash tales have been written down and published in Russian by the artist and ethnographer V. Charnoluski (Charnoluski 1962, 1965, 1972). Eero Autio has published the folktales of V. Charnoluski in the Finnish (1993) and Kerstin Eidlitz Kuoljok in the Swedish language (Tjarnoluski 1993).

Eero Autio has also analysed the totemistic aspect of the Meandash folktales (Autio 1993, 1995). Besides him, the stories have been associated with the pre-historic petroglyphs by Aleksei Okladnikov and Anatoli Martynov (Okladnikov \& Martynov 1972: 92, 227228), Nina Gurina (e.g. Gurina 1992: 15) and others. The astral folkloristic aspect of material concerning Meandash has been discussed in the work of Heino Eelsalu, a paleo-astronomer (Eelsalu 1995). The current author has also published a series of seven articles on research into Meandash tales in an Estonian electronic journal Mäetagused (Ernits 1997-1999). I would hereby like to express my gratitude to Mare Kõiva, Eero Autio and Andres Kuperjanov for providing me with photocopies of Meandash stories published abroad! 
Tentatively, we might regard the Meandash tales as an entity, namely, as the life cycle of Meandash from his birth to his becoming immortal. Certainly we must consider it an alterable or 'dynamic' entity, which at some point in time might appear static, as new motifs and versions are being created or borrowed, or when the tales merge into one, etc.

The life of Meandash can be subdivided into the following parts, which we might refer to as periods or stages:

1. Birth and youth: a) birth and childhood, b) leaving his mother;

2. Manhood: a) marriage, b) leaving his wife and children;

3. Meandash as a culture hero;

4. Meandash as a deity: a) a sky reindeer pursued by a thunder deity, and b) a sun deity.

\section{BIRTH AND YOUTH}

The first period in Meandash's life is preceded by an introduction of his mother's sexual life, including impregnation. Meandash's birth and boyhood is described in five of the recorded versions.

The first account (n.b. see the index at the end of this article) is concerned with the following: In a world away from people, the Meandash-maiden gave birth to a reindeer son, who soon learned to hunt. It might seem at first that the events take place in Lapland, but this in not true: the story is located in a mythical place, unknown to mortal Sami people. Still, its climate resembles that on the Kola Peninsula somewhat.

This mythical place is separated from the land of the Sami by a river of blood, which is called the Meandash River (M'aanndashshjoGk). With its waves of lungs and stones of liver it resembles a living organism. The lungs serve as waves and liver as stones in the river of blood. The parallel between liver and stones is truly significant, if we consider the slippery stones and the smoothness of liver. As an anatomist I can picture its surface curving towards the diaphragm. The significance of this organ in the beliefs of the Sami is worthy of more thorough study (cf. the Mesopotamian and Etruscan custom of prophesying on liver - see Ernits 1990). The river of blood has lungs for waves; and, indeed, if a person or an 
animal is lying on its back the sharp edges and the upper pulmonary lobe of the lungs sometimes resemble waves.

The mythical river of blood was known already in the Finnish tradition (Kemppinen 1967: 68). True, the river of blood symbolises the separation of the territories of kin tribes, but it also joins them by means of the circulation of blood. The folktale also reflects the horizontal-divided worldview of the Sami.

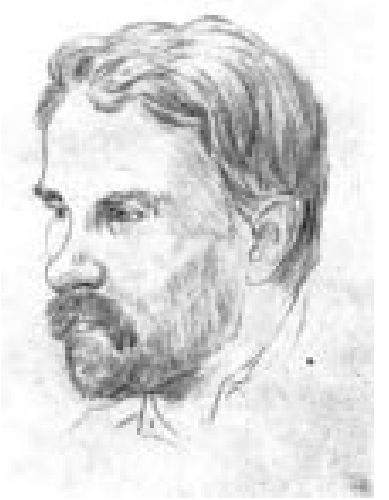

Figure 2. The Sami narrator Piotr Sarvanov. A drawing by V. Charnoluski.

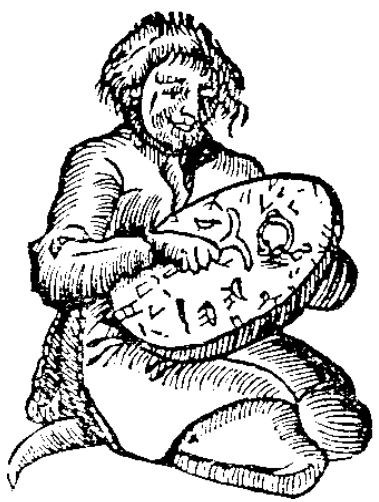

Figure 3. A Sami witch saying charms. After J. Schefferus (1674).
The Meandash-maiden as a young woman and the mother of Meandash, appears in this version only. Other tales speak of an old wise and experienced woman (which in ancient Finno-Ugric tradition suggests a witch). According to the narrator, Meandash-nijt lives in human form, and only becomes a reindeer-cow upon the crossing the river of blood. She has settled in Meandash land with her children, who include the eldest son, whom she has said: "You are meandash - the reindeer," as well as her nameless younger children (reindeer calves). No father is mentioned however. The son did not feed on grass and lichen, as a reindeer would, but instead went hunting, i.e. followed the traditional life style of the ancient Sami.

The second version of the childhood period consists of two stages: 1) the mother's dalliance and 2) helping the mother. The old woman (=witch) took the shape of a reindeer cow and fooled around with horned animals. She got pregnant and gave birth to a reindeer son. The son was strong and healthy and soon started to help his mother with firewood.

The tale says that the woman was an old wise-woman capable of establishing contact between different spheres of universe. 
Nothing is known about her origin, thus she must have existed since the beginning of times; the same also applies to tundra and reindeer. The woman could transform herself into a reindeer-cow as well as a human being, which is typical of totemist beliefs which involve the concept of human descent from animals and the possibility of crossing the line between men and animals. The old woman was impregnated by a horned animal, and gave birth to a reindeer son. An ambivalent human, i.e. a person of split character who was both human and animal, gave birth to an animal.

Her reindeer son was ambivalent as well: he worked as a regular human at helping his mother to gather firewood, he could talk; and, yet, he was a reindeer. The son was no ordinary child, he had exceptional abilities to perform hard labour even as a nurseling. These qualities convinced his fellow tribe members that the times and people were by no means ordinary. It was a mythical time, i.e. a time before us, when the universe was created and arranged as it is now.

When the reindeer son became mature, he became curious about his father and decided to find out whether he was a man or a reindeer. So, he went to cut down a tree and wedged his mother's leg inbetween a wood block there. Then he left his mother and set off to fjeld. Again, this event suggests crossing a line. It is not certain why he had to torture his mother, it is possibly later influence of some fairytale.

The third story speaks of a woman who was married to a reindeer and gave birth to a son who soon started to go hunting. Only the later events of the story of inform us that the son was an ambivalent being, a human reindeer.

The fourth story describes how a woman dallied with the reindeer, became pregnant and gave birth to a human son. The mythical chronotope in the story is relatively weak, it could be inferred only from a single word 'once'. Meandash's mother lived first among the reindeer and later spent her days in a tent together with her son, which in this story can be taken as a reference to her ambivalent nature. This version says nothing of her transformations or of her son's work. The latter became a reindeer only after a reindeer herd (his father among them) approached their tent. The event symbolises the completion of the cycle of time. 
The fifth story is already somewhat familiar (cf. the second story). It is also about helping mother with firewood and fixing her leg inbetween a wood block. In this tale the two incidents of leavetaking - (1) leaving the maternal home and (2) running away from wife and children - merge into one.

A summary on the boyhood tales. Only five variants of Meandash's childhood are known (Table 2), which enables us treat the subject on the argumentative level only.

The variants consist of two to five motifs. The story from Turia contains five motifs and the interpretation of the myth is quite unique. Every motif is repeated two to five times. The incident of the son's departure occurs in every variant. The story of Meandash's birth is known in the whole of the Kola area, but is recorded only as single reports. Two accounts quite similar in their motifs have been recorded from the Kolta people. Also, it is not entirely certain which language group the narrator from Imandra region belongs to.

Three possible explanations have been provided for Meandash's mother:

1. She was a virgin (in Imandra variant);

2. She was married to a reindeer while she herself was a human (in Kildin variant);

3. Dallying around with the horned animals, she herself became a reindeer-cow (in Kolta and Turia variants).

All this indicates that among different Sami tribes the origin of the mother has been interpreted differently.

Parallels could be drawn between the Turia and Kolta variants, at least in the accounts about the mother's dalliance. The Turia story is presented as an aetiological myth, aimed to explain the tradition of hunting reindeer without focusing on the aspect of a culture hero. The occurrence of the horned animal's birth motif in the accounts of both the Kildin and Aahkkel people, proves the affinity of these Sami tribes. 


\begin{tabular}{l|cccccc} 
Motive & $\begin{array}{l}\text { Imandra } \\
\text { region }\end{array}$ & $\begin{array}{l}\text { Kolta I I } \\
\text { variant }\end{array}$ & $\begin{array}{l}\text { Kolta II } \\
\text { variant }\end{array}$ & $\begin{array}{l}\text { Kildin } \\
\text { variant }\end{array}$ & Turia & Total \\
\hline $\begin{array}{l}\text { Mother's } \\
\text { impregnation }\end{array}$ & - & + & - & + & + & 3 \\
$\begin{array}{l}\text { The birth of the } \\
\text { reindeer }\end{array}$ & + & + & - & + & - & 3 \\
$\begin{array}{l}\text { Helping mother } \\
\text { Determining his }\end{array}$ & - & + & + & - & - & 2 \\
$\begin{array}{l}\text { origin } \\
\text { Leaving home }\end{array}$ & - & + & + & - & - & 2 \\
Mother's reaction & + & + & + & + & + & 5 \\
TOTAL & 3 & 5 & 4 & 3 & 3 & 18
\end{tabular}

Tabel 2. The distribution of motives concerning Meandash's childhood.

The motifs of him helping his mother and discovering his origin occurs solely in the accounts of the Kolta. The motif of the mother's reaction (warning her son) is most probably taken from the story concerning Meandash's leaving his family (see below). His leaving home is mentioned in all five of the variants, although in two cases (the Imandra and Kildin variants) it is subsumed into the subsequent departure.

\section{MANHOOD}

\section{Marriage}

The idea of marriage between a human and an animal finds its origin in totemist conceptions (Kostiukhin 1987: 45). Stories concerning the marriage of Meandash might be divided in three subgroups. The first subgroup contains the motifs of crossing the river of blood, the second subgroup introduces the trio of the suitors - a raven, a seal and a reindeer -, the third subgroup is about the bride secretly peeping at the preparation of food. 


\section{THE FIRST SUBGROUP}

The first subgroup of the marriage of Meandash focuses on the following incidents: The reindeer chooses for himself (or has chosen for him) a wife from another side of the river of blood. Out of the three daughters of an old man and his wife, he first marries the oldest, then the middle one, and finally the youngest one. The marriage is successful only with the youngest daughter.

The first story (as well as the ninth and tenth story) contains the intriguing motif of the reindeer son's building up a tent for his future family life. The tent was made of reindeer bones. The close resemblance between the reindeer tent in this story and the one described in Kalevala epic, as well as the similar motif of transforming into an otter, was first seized upon by E.Autio (Autio 1993: 82). In fact, the main difference between the Sami and the respective Finnish material is that in the latter the building is made from the bones of different animal species, whereas in the former the tent is made only of reindeer bones. Although the corresponding Kalevala verses are generally associated with the bridal home at Pohjola wedding, they were originally meant as a description of the room at Toonela (Turunen 1981: 234). Semantically, the Meandash world on the other side of the river of blood and Toonela on the other side of the black river are identical.

Thus, the mythical house of a reindeer was, in fact, a reindeer. The idea clearly refers to the microcosmic concepts and skeleton-re-

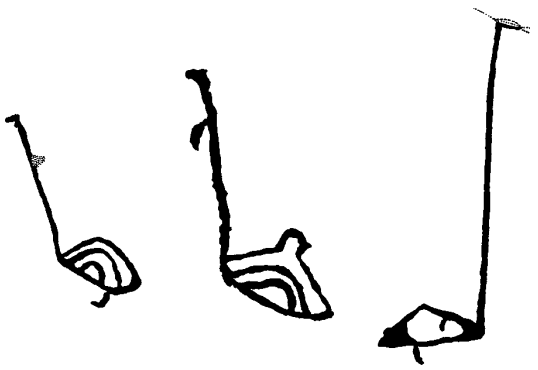

Figure 4. The long-necked swan petroglyphs referring to the magic related to neck. The Neolithic site of rockcarvings at Cape Peri Nos, Lake Onega. lated customs of the Sami. The threshold of the tent were made of cervical vertebrae. A neck is a very vulnerable part of the body: it serves as a passage to one's soul; therefore, it must be well protected.A number of swan images with necks several times longer than their bodies have been carved on the petroglyphs around Lake Onega during the Neolithic period. That, again, refers to the significance of the neck in ancient beliefs. 
On the one hand, the threshold functions as a guarded border between the micro and macrocosm, on the other hand it serves as a part of the building which connects these two. A neck serves as a guarded border between the inner and outer space and connects the head with the body - probably the thought of making a threshold from cervical vertebrae was based on this very fact.

The reindeer surrounded the purification site with thoracic vertebrae, which really is quite logical: the thorax, containing heart and soul, is considerably more secure and cleaner than the abdominal cavity containing liver and intestines. Apparently, the Finnish Sami have considered the spinal column and sternum as the most important bones in a human body (Itkonen 1946: 246). It is also believed that a part of the soul-matter is retained in the bones, supposedly because the bones are preserved longer than other organs (Paulson 1958: 238). Bones are said to be associated with one's ancestors; for example, during the collective feasts the Sami, and also the Turkic peoples shared an animal body between them in a very specific way. It is assumed that the sharing is performed on the principle of demonstrating the identity of both structures - the community as a social organism and the body of a sacrificed animal (Tradicionnoe mirovozzrenie 1990: 39, 42, 43).

Two of the three daughters of the old man and his wife are evil and disobedient, they even steal. And, usually, the wages of sin is death. In the present story they are turned into lifeless stones, as such wretched women could not become the ancestors of reindeer people.

Unlike her older sisters, the younger daughter was able to chant. She chanted the river of blood into drying off. While doing so, she chewed alder bark and spit the cambium into the river. Alder is the hypostasis of blood. In ancient times its reddish sap was thought to contain blood; according to T. Lehtisalo it became the sacred soul tree for the Finno-Ugric people for this very reason (Lehtisalo 1934). I. Sergeieva has argued that alder was also considered a magic tree by the Sami, and its bark broth was used in a number of rituals (Sergeieva 1994: 167-168). The ritual of chewing alder bark, then spitting the red gunk all over the hunter was performed also during Bear Wakes (Krohn 1906: 179). Furthermore, the forest master of the Sami was called the man of alder, or Leeaibe-olmmai. 
Analogous magic is present also in the current story: blood could be dried off only with alder (= the substitute of blood) and the "Meandash-joGk became drier than dry." A similar motif of chewing an alder branch and spitting the cambium into water while crossing the river occurs also in a story recorded from one of the Kolta in Suynnijel, where a mother seeks a wife for a dog-man (Itkonen 1931-1936: 171).

The old man's younger daughter cherished the reindeer calves and, by tying red baize ribbons to their ears accepted them as her relatives. The red colour is associated with blood, and, by that token, also with ancestors. Thus it is sacred. In the blood river story, the category of acceptance is clearly proved by a Kildin Sami belief that seeing blood in one's dream predicts a relative's visit (Szabò 1967: 44-45).

The Sami thought that soul resides in ear (Charnoluski 1972: 112). Ears were also sacrificial organs for the Sami (Leem 1771: 215216). It is also known that in Aahkkel, red cloth laces had been tied to the reindeer horns lying heaped up in piles; by offering the horns people hoped for a good hunt (Charnoluski 1966: 308).

In the sixth story the bereaved reindeer transformed into a Sami and proposed to the oldest daughter of the insofar mortal Sami man from the other side of the river of blood. Later he married the middle daughter, and then the youngest. The daughters' behaviour was the same as in the earlier versions. The evil ones were gored to death.

The current version is characteristic in the way that the reindeer was a widower and he had children from his first marriage, who were also reindeer. Apparently, the marriage stories are didactic in nature, teaching people to revere the totem for fear of death.

In the Sami accounts, the river of blood separates the land of mortals and the mythical reindeer land. It functions as a border between the realm of the dead and that of the living, between companions and the ancestors. Therefore, the black river of the Underworld and the River of Blood are express the same semantic notion: both of them function as borders between our world and the other world. One of the interesting features here is that one of the daughters 
crossed the river by swimming like an otter (Autio 1993: 82). The mythic nature attributed to otters in Finno-Ugric tradition is revealed by a huge petroglyph discovered on Besov Nos among the Neolithic rock-carvings of Lake Onega. Its living habits make this precious fur-animal a perfect mythic mediator between the different spheres of universe. It swims in water and also moves on dry land, occasionally standing up on two legs and assuming the pose of praying. All this makes it an ambivalent character.

The seventh story has reached us only as a fragment similar to the previous ones in its motifs of the river of blood and chanting.

\section{THE SECOND SUBGROUP}

The second subgroup mainly focuses on the following details: The raven married the old man's (and his wife's) oldest daughter, the seal married the middle one, and the reindeer married the youngest daughter. The old man and his wife went to visit their daughters and saw that the only daughter living happily was the one married to the rein-

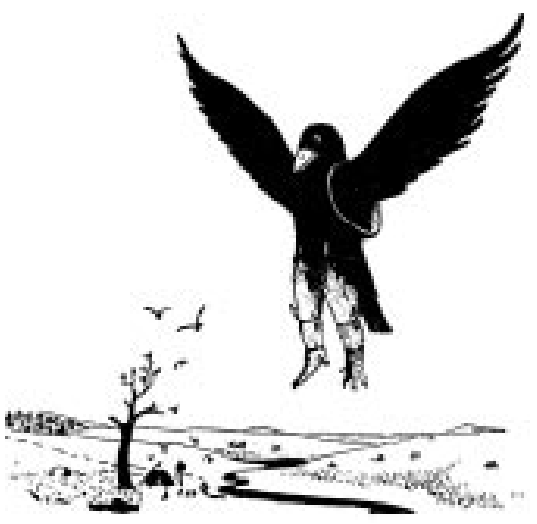

Figure 5. The raven son-in-law. A drawing by V. Charnoluski. deer. The only similarity between the second and the first subgroup of stories is that it is the youngest daughter of the old man (or the mortal Sami man) and his wife who is married to a reindeer.

Figure 6. The seal son-in-law. A drawing by $V$. Charnoluski.

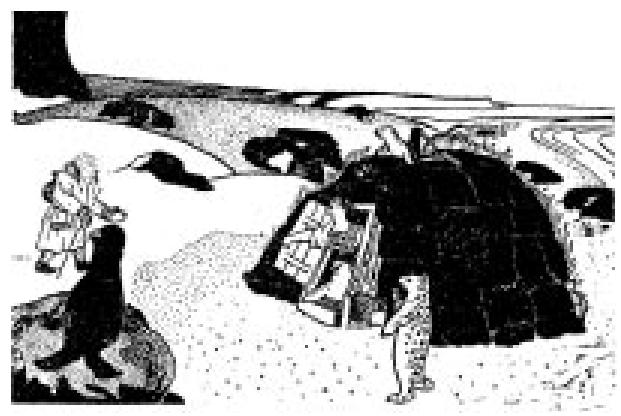




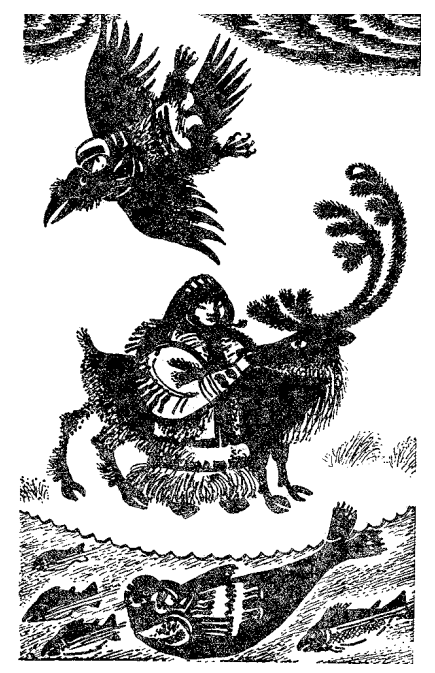

Figure 7. Three suitors. An illustration by V. Petrov, after Sangi 1985. The artist has had a vision of a three-sphere universe.

The eighth story is already familiar in its contents (see also the seventeenth story). V. Charnoluski has recorded two stories with the same title: one from Aahkkel and the other from Turia (cf. the 13th story). The Aahkkel version is very characteristic to the Meandash's marriage of the second subgroup, although the proposal motif is rather brief.

I. Sergeieva speculates that the three animal suitors in the second subgroup symbolise the three worldly spheres: the raven - sky, the seal water, and the reindeer - earth; and therefore it suggests the personification of nature and the belief in the blood-relation between men and animals (Sergeieva 1994: 164).

The present author does not exclude the possibility that the three characters might represent different totems. The current variant suggests that the parents of the child came from different tribes: the totem of the father was a reindeer, while the mother's totem was a raven. And even if the wife did not like it, things were decided by her husband. Moreover, a raven has also been one of the main characters in the mythology of the arctic peoples of Siberia (see Meletinski 1979).

Generally, the events described in myths centred around a journey, the same applies to this subgroup, where the old man and his wife take turns to visit their daughters. The old man who came from the reindeer tribe was not happy in the raven's family, with its bare living-place and the dried pine-trees, and its disorderliness, and a diet of odds and ends. Such a lifestyle was not something a reindeer was accustomed. For some reason the raven was hostile towards the reindeer's oldest daughter and had crippled her; still, they lived together and had children, who were all ravens due to their dominant father. 
Then the old man visited his middle daughter, who had married a seal, and found that the seal was not a good husband for his daughter either. Again, he disapproves of the vast emptiness, the becoming-dirty from the seal blubber, the unaccustomed food and the son-in-law's hostility towards his daughter.

The next day the old man visited his younger daughter. In this story, the distinction between one's-own and the strange is most conspicuous. The latter is characterised by unaccustomed things, deficiency and ugliness, whereas the former (including nature) is habitually fine and beautiful. The land is covered with the basic foodstuff of the reindeer, lichen. One's own people are revered they are offered the best seat covered with soft fur. It is good to live among one's own people, therefore the old man settled among the reindeer family, at first, alone, but later along with his wife. Another significant fact is that the reindeer son-in-law was the only one to be transformed into a human being, whereas the others remained animals. This fact strengthens the sense of one's own even more.

The story tells of the game of the reindeer, which according to V. Charnoluski was a remnant of the collective hunting cult, and resembles ikänipkä, the ritual feast of the Evenki (Charnoluski 1966: 310 ff.). The reindeer game had been described even earlier by N. Haruzin and journalist Zinaida Richter in 1925 (see Haruzin 1890: 340, 383).

The tent symbolises the first member of the pair of opposites - culture and nature -, separated by the walls. Outside the tent, the reindeer represented hypostasis of animal, inside the tent where he was married to a human he assumed an anthropomorphic shape. The tent where the old man came to was located in the other world: had he been a stranger he would not have been able to enter the tent. He had to be let in by a relative - in our story, the wife of the reindeer.

The ninth story is seems to be the only story recorded twice from the same narrator, after the gap of a year. Although the first version of it was mediated by the narrator's student daughter, this is still quite a typical version. The motif of proposal is treated in a relatively laconic manner. The interesting feature of the story is 
that the reindeer used one door to enter the tent while his wife used another. Traditionally, the Sami hunter took his haul to the tent through the back door (poashsh-uks, also veerr-lypps, i.e. the blood door), and then entered the building through the front door (Charnoluski 1966: 307). Turkic peoples have a similar tradition: the products of the strange world (the hunting haul) are never taken to the house through the front door (Tradicionnoe mirovozzrenie 1988: 70), for it would involve a clash between the cultural and natural world. The reindeer in our story is simultaneously the hunter and the haul, as he chases animals of his kind.

The second variant, which was recorded directly from M.Antonova, differs from this account only in three details:

1. The three suitors came to propose at the same time;

2. The old man gave them a task to carve out three piggins, and the suitors succeeded at it;

3. The raven fed on tripe and heads.

The simultaneous arrival of the suitors occurs also in the sixteenth story and the carving of piggins in the fourteenth story (see below); both of these were recorded in Turia.

The tenth story differs from the others only in smaller details. This variant emphasises the significance of predictions appearing in dreams. The old man's wife dreamt only of the most characteristic body parts of the animals (totems). The dream was not an ordinary one, but had a special meaning, being seen before the marriage of her daughters. Differently to the previous variant, the proposal scene is almost skipped, which might be accounted for by the narrator's forgetfulness.

As to the reindeer, it is said that his tent was made from bones and skins, so, the reindeer tent must have been similar to the ones described in previous versions. The motif of pre-marital building of the tent seems to have been forgotten, and it functions only as an insignificant detail which makes the reindeer more agreeable than the other suitors.

It is possible that the eleventh story has been passed on from the Kildin to the Turia people. This story introduces the idea that all the suitors had the powers to take the shape of human. 
The first part of the twelfth story, namely the account of marriage, is relatively similar to the previous version, although the proposing scene is described more thoroughly. The story relates that the old man had not yet waken up, while his wife was already lighting the fire. She is always the first one to notice the suitor, whereas the old man takes up the subject of marriage. The old woman names the body part most characteristic to the animal (pars pro toto); doing it in most of the versions. The story is a typical expression of totemist philosophy: an animal who can transform into a human being, marries the daughter of a human. Quite significant is the emphasis on the time period - it always happens in the morning. It is common knowledge that in myths, morning is associated with creation (Tradicionnoe mirovozzrenie 1988: 47).

The animal suitors are rather active: they come from a distant place (or, in fact, the mythical world) and ask the old man's permission to marry his daughter. Let us recall here that in the first subgroup it was the young reindeer's mother who went to seek a wife for her son. The narrator's attitude towards all of the suitors is rather favourable, although somewhat uneven: the raven is considered a handsome man, the seal a plump one and the reindeer an exceptionally handsome man.

The proposal scene is soon followed by a visit by the old man and his wife. Life in Meandash world as well as in human world was thought to be regular. In the morning they got up, the husband went hunting, then they ate dinner and went to sleep. The passage of time is constantly emphasised (e.g. "life went on.."). Grandmother had a kind and warm attitude towards her grandchildren - it is shown by her making red collars for them. These are semantically comparable to the red baize ribbons mentioned in the first story (see above), which were tied around the ears of reindeer calves.

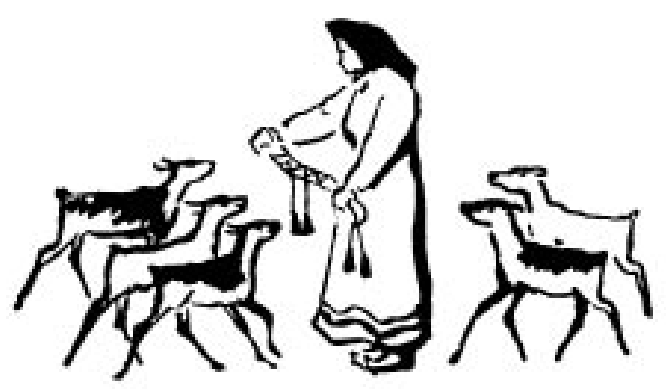

Figure 8. Tying ribbons around the reindeer calves' necks. An illustration by N. Kostrov after V. Charnoluski 1962. 


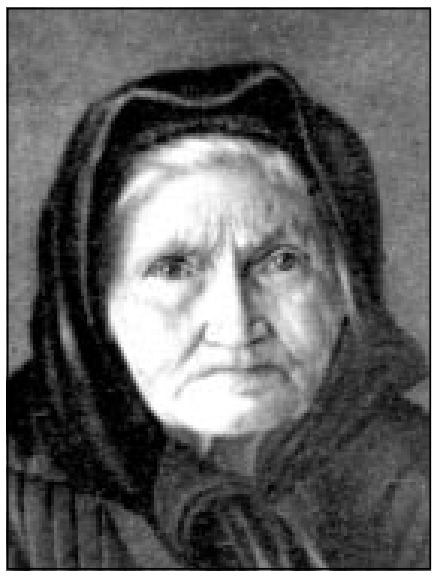

Photo 2. The Sami narrator Tatiana Danilova. After V. Charnoluski 1965.

The worship of totems was still current at the time when Charnoluski made his expedition to the Kola Peninsula, although for obvious reasons the local people were not over-eager to discuss it with strangers. Later, however, they overcame this timidity.

In Sami folk religion, the reindeer is associated with male lineage. In the Sami language, the wife of Meandash was usually called Meandashsh-kaab or $k o a b$, where the last part of the compound stands for a newlywed or a young married wife, (and is related to the Estonian dialectal words $k a b e$ and $k a b u$ [maiden, woman]). T. Danilova has also called her the maadder-ahke, or the ancestress (cf. the Kolta word maaddar-ahkka and the Inari madderakko, etc.) (Ränk 1949: 188; Itkonen 1943/1944: 65). The first part of the compound is related to the Finnish word manner : manteren [continent] and the Estonian cognate the Estonian word manner : mandri. Relying on the Kalevala, we might assume that originally the Sami word denoted also 'Earth Mother', it is even supported by the linguistic record that in Finnish mythology, the wife of Ukko, the thunder god was known as akka (Turunen 1981: 18). The Finnish historian, Uno Holmberg, has mentioned that Madderakka, who helped women in child labour, and is therefore considered as the ancestress, lived in the ground under the tent where people took offerings for her (Holmberg 1915: 77).

V. Charnoluski has reported that this version had never been told in the form of a narrative, it has always been sung. The story was called the lyvt.

As for the thirteenth story (see also the eigth story), we cannot exclude the possibility that it might have come from one and the same original version: whereas one of the stories is narrated with a longer beginning, the other has a longer ending. The story might have been 'improved' by V. Charnoluski, as the collector is suspected 
to have added information to story and merged different versions on many occasions.

The fourteenth story is the first, and so far the only reindeer story, that has been translated into Estonian. This version has clearly been influenced by the Indo-European miracle fairytale The Frog Princess (AT 402), where the suitors have to fulfil complicated tasks and where the woman burns her husband's skin (e.g. Arājs \& Medne 1977: 61-62, 281; Barag et al. 1979: 128-129). The motif of carved piggins occurs also in the 9 th story, which is recorded from Turia as well.

The fifteenth story has been quite thoroughly elaborated. In the beginning, the suitors are merely characters disguised in animal costumes. The narrator has paid a lot of attention to the first marriage. Differently to the previous versions, the wedding ceremony takes place in the bride's parental home. Another intriguing fact is that the newlywed bride leaves her parental home flying like a raven. We should remember here that in Sami folk religion when the soul of a shaman took the shape of a bird, it travelled most often as a raven (Paulaharju 1922: 136). Also, a seita-stone driven away from its home, or a deity living there often appeared as four ravens (Nemirovich-Danchenko, s.a.: 364). Another unique description reports that the third suitor left his bride's parents in the shape of a reindeer, his wife followed him as a reindeer-cow.

Before the departure of the son-in-laws, the old man asks where the newly-wed couples intend to settle down. The raven and the seal replied, a house by a sea-cliff, but the reindeer's answer was, a tent set up near a forest lake. These replies suggest that different tribes were settled in different regions, and also that the raven and the seal were considered quite respectable in this story. The folktale differs from others also in the fact that the seal was not totally condemned.

Life is best in the reindeer family, where the (presumably humanshaped) children play with reindeer horns (cf. the eighth story). The gradation of children seems to function as praise or blame as well: the raven's children are all animals; the seal's animals are partly animals, partly humans; the reindeer's children are all human. 
The sixteenth story says that the three (anthropomorphic) suitors met the old man at a reindeer hunt and promised to marry his daughters all at once (similar 'collective' proposals occurs also in the 9 th story) the same evening (!). The suitors turn up at the time promised and the daughters choose their husbands. Thus, the basics of the story are familiar, although the details differ from other versions considerably. Apparently, the narrator was uncertain in his facts.

In this version, it was also the old man who went to visit his daughters, although the fact that he first visits the seal family is an obvious lapse of memory. So is the mentioning of fish on reindeer's dinner table. The story differs from other variants, in the fact that the parents intended to save their daughters from misery, but nothing came of this.

The seventeenth story resembles the eigth story in its description of the origin of the daughters' parents. The commentary to Sami Folk Tales (1980, edited by G. Kert) note that the folktale Why Don't the Reindeer Live Among People? (the seventeenth story) is taken from V. Charnoluski's book A Legend of Meandash, the Human Reindeer (Kert 1980: 296). In reality, this book contains no such folktale! The folktale is in fact taken from a book entitled $\mathrm{On}$ the Land of the Flying Stone by V. Charnoluski (Charnoluski 1972: 114-117). Further comparison reveals that the seventeenth story is actually the same as the eighth story, for they accord in contents, and are in many ways the same. Still, as they contain quite conspicuous differences, they cannot be considered as totally identical. What, then, might be the problem?

The preface to Sami Folktales reveals that some of the folktales that had not been previously published, were obtained from V. Charnoluski's son, and that these are edited for literary reasons (Kert 1980: 5). We can assume that the story Why Don't the Reindeer Live Among People? is one of them. Thus, V. Charnoluski must have written two literary versions of the same recorded narrative, and left the more thoroughly edited version unpublished. Therefore, there is no need to analyse the contents of the seventeenth story once again; instead, I will present a few supplements which occur in the story: 
1. It emphasises that the reindeer of the old man's tribe are clean animals who "care for their appearance, and their blood", adding that all excess things are cast into water and not put in store. Further events suggest that the reference applies to the bedfurs peed wet by children;

2. The sea-related ravens and seals are said not to care for their appearance; they smear themselves with gore, eat meat and blood, store and hide the leftovers, and are in the habit of smelling bad;

3. The description of the motif of proposals by the raven, seal and reindeer is more worked out, as is that of the conflict caused by the difference in origin of the parents. The reindeer is called Meandash;

4. The seal's home was built of whale bones. This detail occurs in none of the other variants;

5. The old man shivered from cold sleeping under the seal skin cover;

6. After greeting, Meandash laid his hand on the father-in-law's shoulder and the old man laid his hand on his.

In the myths and folktales, the youngest daughter is often held in the highest esteem. Logically, both parents wished to marry their favourite child to an animal representing their totemic group. The same happened in this version of the story: the old woman tried to fix her youngest daughter up with the first suitor, the raven, whereas the old man wanted to give him the oldest daughter. In both cases it was the old man's word that decided the matter. The old woman also wished to marry the youngest daughter off to the seal, but the old man had other plans. A discussion of the different totems of raven, seal and reindeer predating the present article is that of Eero Autio (Autio 1993: 68).

Figure 9. A bone spoon. After Kodolányi 1975. Were the reindeer images on items made by a carver who

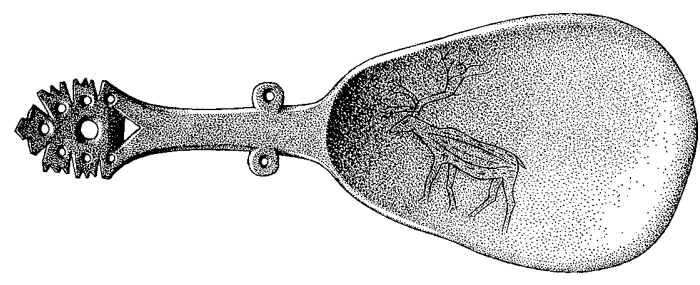
had considered this wild animal as his totem? 
The eighteenth story is rather distorted. Firstly, it is expressed in the strange account of the old man sending his daughters to the seashore to seek husbands - this idea might have been borrowed from another folktale. Also, the idea of finding the reindeer husband there seems implausible. Secondly, the canonical order of marriages, typical of other stories, does not apply here: in this version, the seal marries the oldest and raven the middle daughter; the first visit, however, coincides with that in all other versions. Thus, the differences might have been caused by the narrator's memory lapses, or simply his ignorance in the contents of the myth.

The emphasis on male lineage is prevalent in all previously-mentioned and following versions of the story - this emphasis is even reinforced by the patrilocal residence: the wife, children and the elderly parents live all together at the husband's house.

We should be careful in analysing the nineteenth story, as the narrator is young and educated. The proposal-event is quite traditional in itself, the suitors came one after another. Lighting the fire is also mentioned, introducing the use of a vent for hot air. The raven and the seal are referred to simply as young men, whereas the reindeer and his horns are considered exceptionally handsome and nice, which, again, refers to the narrator's preference. The narrator mentions that neither the ravens flying above the house, nor the seals' sliding down the slopes. It is said that the raven and seal children ran to meet their grandparents, shouting: "Grandmother and grandfather are coming to visit us." The same happened in the reindeer home. Grandmother made crochet red ribbons for each of her grandchildren; the neck or ear laces have also been mentioned also in the first and the twelfth story.

\section{THE THIRD SUBGROUP}

The two versions of the third subgroup might be considered as contaminated accounts of the marriage of the reindeer and the dog.

The twentieth story describes the story of a dog-man interrelated with the story of a reindeer-man; the former is known in the whole of the Kola Peninsula, and even among the Finnish living in Kolta (e.g. Briskin 1917: 7-9; Itkonen 1931-1936: 8, 170-175, 194203; Itkonen 1985: 94-101; see also Kert 1961: 56-61). 
The characters of the folktale are:

1. an elderly woman with her dog-man son;

2. the three daughters of an old man, one of whom will be the future wife of the dog-man;

3. the son of the dog-man and the youngest daughter.

The story introduces the elderly woman as a fully human being, whereas her husband, already dead by that time, was half-human, half-dog. Therefore, we might assume that he was a representative of the dog totemism. Several Ob-Ugrian ethnic groups have considered dog as their ancestor, or as a sacred animal (Sokolova 1983: 140).

The Sami folktales suggest the existence of at least five totem animals: a reindeer, a raven, a seal, a dog, a bear and a falcon. This is also suggested by archaic remnants discovered at archaeological excavations. During the last decade, eighteen zoomorphic figures have been found at the Kola Peninsula, four of them deer-like, four bear-like, three dog-like, one a supposed marbled seal, and so on. (Gurina 1986: 4). In addition, the Sami believed in the transformation of humans into a salmon trout as well as to a pike (Itkonen 1931-1936: 74-75; Charnoluski 1962: 187-190).

The second exogamous group in the current story was formed by the descendants of the reindeer, including both the mother-in-law as well as the daughter-in-law, as both of them started to give birth to reindeer children. The mother's warnings also refer to the reindeer who snares dogs with reindeer traps. Similar stories can emerge only among a mixed group of people who consider both dog

Figure 10. A lovely dog. Illustration by N. Kostrov, after V. Charnoluski 1962.

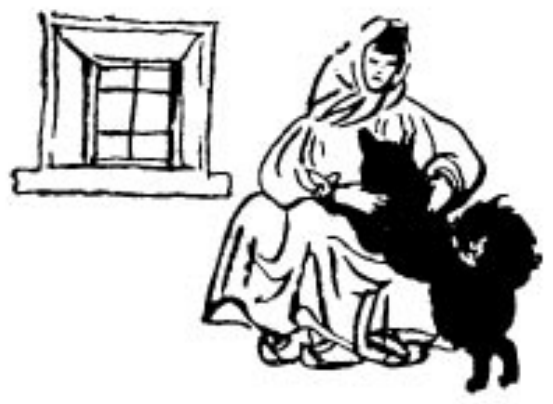


and reindeer as their ancestors; this argument, however, appears to be flawed, if we note how the dogs regard stench (which is a link with the reindeer stories).

The general structure of the current version resembles the first subgroup of marriage stories, in that the disobedient older daughters are condemned to death. This disobedience is not just a refusal to comply, but a violation of an important taboo of the dog's family connected to boiling meat. The story suggests that the newlywed woman must adopt her husband's life style, which was passed on to him in turn by his half-man, half-dog father. The reindeer mother's task after losing her husband was (or was not, in cases where there was no husband, as in the stories of the first subgroup) to marry her children in the benefit for the whole fratria; she has also the right to punish them for violating the husband's family's traditions.

According the V. Charnoluski, the twenty-first story is taken from the records of A. Genetz (Charnoluski 1965: 35). This, however, is not true. If this story is not V. Charnoluski's own crossing of K. Haruzin's version (i.e. the nineteenth story) with marriage stories of the first subgroup (the motif of goring to death, for example, occurs in the sixth story), then it must be an otherwise unrecorded story collected by V. Charnoluski.

The events described in this story take place in mythical times. The childhood of the reindeer, who is by that time ready for marriage, is summed up in a single sentence, mentioning his unusually-fast maturation. The parents of the young man, called grandmother and grandfather were both (erroneously!) said to have belonged to the reindeer tribe.

The most intriguing fact is that the first candidate for wife is brought home by the grandfather, while all the others are brought home by the grandmother. The reindeer mother turned the first maiden into lifeless stones, i.e. punished her with death for breaking the meat-boiling taboo. In both this and the nineteenth story, the future mother-in-law discovered her offence when the leather sack containing meat started to let water leak over the fire. 
Differently to the previous version, the second prospective wife was too bashful and indifferent towards her future husband. This also was considered reprehensible: she was first gored to death by the reindeer, and then turned into a stone.

The youngest daughter met the reindeer's expectations and they lived happily from then on (the tying of ribbons or neck collars was described also in the first and the twelfth story).

The encircling of the tent by a reindeer herd seems to refer to it being occupied by totem animals. The Tenojok Sami, for example, had a custom related to proposals of marriage, namely, that of riding three times around the house of a bride-elect (Mark 1928: 102). The practice of turning on one's heels followed by a transformation or some other significant change has a somewhat different meaning. It occurs in the Meandash-series (e.g. the 1st story), and elsewhere (see Itkonen 1931-1936: 72). In an account of proposal of marriage from Nyörtsaame, the young couple turn three times on their heels (Zaicev 1927: 22). Might that be considered a relevant feature of transition rites?

\section{The versions of Meandash-stories:}

1. Miandash-nijd-Miandash-deva. V. Charnoluski, 1936 < Piotr Sarvanov (also Sorvanov; about1877-1943). Imandra, Monnch. Published in Russian in Charnoluski 1962: 84-92, 1965: 55-62; Kert 1980: 198-202 (No. 129).

2. Kod'd' agka- Dikaia starukha. K. Shchekoldin, 1887 $<$ M. Fedotov. Kolta, Pattshiesid. Published in Russian in Shchekoldin 1890: 163, Charnoluski 1965: 25 (abbreviated), Kert 1980: 221 (No. 138).

3. Kå’nd maajnas - Märchen vom Wildren. E. Itkonen, 1943 $<$ Maksim Antonov (born in 1919). Kildin, Shongui. Published in Sami and German in Itkonen 1985: 14-15.

4. Skazka pro pyzhika-ditia. V. Charnoluski, 1927 < Varvara Kuropteva (born in about 1867). Turia, Iovkyi. Published in Russian in Charnoluski 1965: 29, Kert 1980: 221-222 (No. 139). 
5. T. I. Itkonen, 1927 < Mikko Fedotov (born in about 1907). Kolta, Pattshiesid. Published in Sami and Finnish in Itkonen 1931-1936: 70-72.

6. Skazka o dikom olene. A. Iashchenko, 1887 < Imandra region, Chukksuöl(?). Published in Russian in Iashchenko 1892: 34-35, Kert 1980: 202-203 (No. 130).

7. I. Sergeieva, 1990 < Lazar Iarovlev. Kildin, Luiaur. Published in Sami and Finnish in Sergeieva 1994: 167 (fragment).

8. Olen' dikar' [I]. V. Charnoluski, 1927(?) < Maksimych. Aahkkel, by the Churozero. Published in Russian in V. Charnoluski 1972: 114117.

9a. Pro vorona, tiulenia i dikogo olenia. Georgi Kert, $1954<$ Anna Antonova < MariaAntonova (1900). Kildin, Teriberka. Published in Sami and Russian in Kert 1961: 158-162.

9b. Skazka pro zhenshchinu i dikogo olenia. Georgi Kert, $1955<$ Maria Antonova (1900). Kildin, Teriberka. Published in Russian in Voskoboinikov \& Menovshchikov 1959: 27-28; Sangi 1985: 13-16.

10. Tiulenii lasty. G. Kert, 1959 < Agrafena Arhipova (1903). Kildin. Luiaur. Published in Sami and Russian in Kert 1961: 79-81, 1980: 218-219 (No. 136).

11. A. Genetz, 1876 < ?. Turia, Iovkyi. Published in Genetz 1878: 330 (summary under keywords Mintysh and Meantash-ajk), 1879a: 11, 1879b: 145-146 (in Sami), 1891: 241-242, 279-280 (in Sami and Finnish).

12. Lovta o Miandashe. V. Charnoluski (1927) < Tatiana Danilova (born in 1874) < first husband Ilia or A. Matriokhin (died in about 1918). Turia, Kintush. Published in Russian in Charnoluski 1962: 94-101, 1965: 85-90, Kert 1980: 204-207 (No. 131).

13. Olen' dikar' [II]. V. Charnoluski, 1927(?) < ?. Turia, Iovkyi. Published in Russian in V. Charnoluski 1965: 41-42, Kert 1980: 212 (No. 133).

14. KonDe maiNS - Muinasjutt metsikust põhjapõdrast. Victoria Sienkiewicz-Gudkova, 1955 < Ustinia Tarunova (born in 1899). Turia, 
Iovkyi. Published in Sami and Estonian in Sienkiewicz-Gudkova 1960: 213-214.

15. Konte majNs - O dikom olene. G. Kert, $1960<$ Maria Matriokhina (1900). Turia, Iovkyi. Published in Russian in Kert 1980: 214-218 (No. 135), in Sami and Russian in Kert \& Zaikov 1988: 93-100, 171175 (No. 47).

16. Koolmm vyer'pen' - Tri sestry. G. Kert, $1960<$ Maria Danilova (born in 1903). Turia, Iovkyi. Published in Sami and Russian in Kert \& Zaikov 1988: 110-115, 182-184 (No. 51).

17. Pochemu oleni zhivut otdel'no ot liudei. ? < ?. Published in Russian in Kert 1980: 207-211 (No. 132).

18. Dedushka u vnukov. J. A. Komsilov, 1920-1930<?. Published in Russian in Kert 1980: 212-214 (No. 134).

19. Kolm n'iid - Drei Töchter. L. Szabò 1964 < Zinaida Iakovleva (born in about 1937-1938). Kildin, Kordagk. Pubished in Sami and German in Szabò 1967: 99-103.

20. Sobach'ia skazka - Penyj majnas. K. Shchekoldin, $1887<$ M. Fedotov. Kolta, Pattshiesid. Published in Russian in Shchekoldin 1890: 161-162, Haruzin 1890: 43-44, Kert 1980: 222-224.

21. Skazka pro dikikh olenei. ? < ?. Charnoluski 1965: 36-37.

22. Pro dikikh. V. Charnoluski, 1936 < grandmother Fedosia. Aahkkel. Between Churiauri and Imandra. Pubished in Russian in Charnoluski 1972: 111-112, Kert 1980: 219-220 (No. 137).

23. Molitva Miandasha. V. Charnoluski, 1936) < Myhkal Kitov. Kolta (?), Tuallama. Published in Charnoluski 97-98, Kert 1980: 197-198 (No. 128).

24. Gornyi dukh. Vassili Nemirovich-Danchenko, $1873<$ Kolta, Suonnijel. Published in Nemirovich-Danchenko 1877: 209, 362, Kert 1980: 196 (No. 126).

25. Gornyi dukh. Vassili Nemirovich-Danchenko, 1873 (?) < Kolta, Suonnijel. Published in Nemirovich-Danchenko 1881: 170-171; Koshechkin 1983: 55. 
26. Olen'zlatorogi. V. Charnoluski, $1927<$ Iestrat Nikandrovich (in about 1860). Turia, Iovkyi; Vassili Tiolyshev < Ilia and Filosof. Turia, Lymbes < Kintush. Published in Charnoluski 1962: 80-81, 1965: 8081, Kert 1980: 196-197 (No. 127), Koshechkin 1983: 55-56.

27. S. Paulaharju, 1910-1920 < ?. Kolta. Published in Paulaharju 1921: 148-149.

28. Chto takoe grom? G. Kert, P. Zaikov, 1971-1974 < Fiodor Sergin (1924). Aahkkel, Babino v Ienu. Published in Kert \& Zaikov 1988: 129 (No. 11).

29. Miandaš-pyrre. V. Charnoluski, 1927? and 1936? < (?) Piotr Sarvanov (born in about 1877- 1943). Monnch; (?) Iefim Danilov (born in about 1859) < Ilia and Semion. Turia, Lymbes. Published in Charnoluski 1962: 82-83, 1965: 74, 1971: 89, Koshechkin 1983: 110 .

Translated by Kait Realo

\section{References}

Arājs, K. \& Medne,A. 1977. Latviešu pasaku tipu rādītājās. Rīga. Autio, E. 1993. Kultasarvipeura ja sen klaani: Totemisia taruja ja menoja Kuolan niemimaalta. Jyväskylä.

Autio, E. 1995. The Possibility of Totemism in the Interpretation of the Ancient Rock-Pictures in the Baltic Area. Castrenianumin toimitteita, 49, pp. 180-202.

Barag, L. G. \& Berezovski, I. P. \& Kabashnikov, K. P. \& Novikov, N. V. 1979. Sravnitel'nyi ukazatel'siuzhetov: Vostochnoslavianskaia skazka. Leningrad.

Briskin, N. 1917. Loparskie skazki. Arhangel'sk.

Charnoluski, V. V. 1962. Saamskie skazki. Moskva.

Charnoluski, V. V. 1965. Legenda ob olene-cheloveke. Moskva.

Charnoluski, V. V. 1966. O kul'te Miandasha. Skandinavski sbornik. Tallinn, pp. 301-315.

Charnoluski, V. V. 1972. V kraiu Letuchiego kamnia: Zapiski etnografa. Moskva.

Eelsalu, H. 1995. Rahvaluule mõistatuslik valge põder. Keel ja Kirjandus, nr 9, pp. 611-616. 
Ernits, E. 1990. Loomohver ja tulevikumärgid: Etüüd anatoomia seosest mantikaga. Eesti Loomaarstlik Ringvaade, nr 4, pp. 1924.

Ernits, E. 1997-1999. Hõimlane verejõe tagant: Saami muinaslood tootempõhjapõdrast, 1-7. Mäetagused, 4-10. Tartu.

G[enetz], A. 1878, 1879a. Matkamuistelmia Venäjän Lapista. Suomen kuvalehti, 141, pp. 328-330; 145, pp.10-11.

Genetz, A. 1879b. Orosz-Lapp nyelvmutatványok: Máté evangélioma és eredeti textusok. Nyelvtudományi Közlemények, 15. Budapest, pp. 74-152.

Genetz, A. 1891. Kuolan Lapin murteiden sanakirja ynnä kielennäytteitä. Bidrag till kännedom af Finlands natur och folk,50. Helsinki.

Gurina, N. N. 1986. Nekotorye obrazcy izobrazitel'nogo iskusstva drevnikh plemen Kol'skogo poluostrova. Kratkie soobshchenia, 185: Pamiatniki neolita i bronzy. Moskva, pp. 3-9.

Gurina, N. N. 1992. Naskal'nye izobrazhenia Kol'skogo poluostrova. Rossiiskaia arheologia, 3, pp. 5-17.

Haruzin, N. 1890. Russkie lopari. Izvestia Obshchestva estestvoznania, antropologii i etnografii, 66. Moskva

Holmberg, U. 1915. Lappalaisten uskonto. Suomensuvun uskonnot, 2. Porvoo.

Iashchenko, A. 1892. Neskol'ko slov o Russkoi Laplandi. Etnograficheskoe obozrenie, 1, pp.10-37.

Itkonen, E. 1985. Kildinlappische Sprachproben. Suomalaisugrilaisen seuran toimituksia, 191. Helsinki.

Itkonen, T. I. 1931-1936. Koltan ja kuolanlappalaisia satuja: I-II. Koltalaisia ja kildiniläisiä satuja, koonnut T. I. Itkonen; III. Jokongalaisia satuja, koonnut D. E. D. Europaeus. Suomalais-ugrilaisen seuran toimituksia, 60. Helsinki.

Itkonen, T. I. 1943/1944. Suomen lappalaisten muinaisuskosta. Kalevalaseuran vuosikirja. Helsinki, pp. 60-74.

Itkonen, T. I. 1946. Heidnische Religion und späterer Aberglaube bei den finnischen Lappen. Suomalais-ugrilaisen seuran toimitteita, 87. Helsinki.

Kemppinen, I. 1967. Haudantakainen elämä karjalaisen muinaisuskon ja vertailevan uskontotieteen valossa. Karjalan Tutkimusseuran julkaisuja, 1. Helsinki. 
Kert, G. M. 1961. Obrazcy saamskoi rechi: Materialy po iazyku i fol'kloru saamov Kol'skogo poluostrova (Kil'dinski i iokangski dialekty). Moskva-Leningrad.

Kert, G. M. 1980. Saamskie skazki. Murmansk.

Kert, G. M. \& Zaikov, P. M. 1988. Obrazcy saamskoi rechi. Petrozavodsk.

Kodolányi, J. 1975. Az észak-eurázsiai vadász-, halász- és réntartó kultúrák. Uráli népek: Nyelvkonaink, kultúrája és hagyományai. Budapest.

Koshechkin, V. I. 1983. Otkrytie Laplandi. Murmansk.

Kostiukhin, E. A. 1987. Tipy i formy zhivotnogo eposa. Moskva.

Krohn, K. 1906. Lappische Beiträge zur germanischen Mythologie. Finnisch-ugrische Forschungen. Bd. 6. pp. 104-111.

Leem, K. 1771.Nachrichten von den Lappen in Finmarken, ihrer Sprache, Sitten, Gebräuche und ehemahligen heidnischen Religion. Leipzig.

Lehtisalo, T. 1934. Lepästä sielupuuna suomensukuisilla kansoilla. Kalevalaseuran vuosikirja, 14. Porvoo-Helsinki, pp. 76-83.

Mark, J. 1928. Lapi pulmakommetest. Eesti Rahva Muuseumi aastaraamat, 4, pp. 101-108.

Meletinski, I. M. 1979. Paleoaziatski mifologicheski epos: Cikl vorona. Moskva.

Nemirovich-Danchenko, V. I. n.d. Strana holoda: Skazki i pesni loparei. 2, izdanie 2. Sankt-Peterburg.

Nemirovich-Danchenko, V. I. 1881. Loparskaia zemlia. Zhivopisnaia Rossia, T. 1. Sankt-Peterburg, ch. 1, pp. 163-184.

Oborin, V. A. \& Chagin, G. N. 1988. Chudskie drevnosti Rifeia: Permski zverinyi stil'. Perm'.

Okladnikov, A. P. \& Martynov, A. I. 1972.Sokrovishcha tomskih pisanic. Moskva.

Paulaharju, S. 1921.Kolttain mailta: Kansatieteellisiä kurauksia Kuolan-Lapista. Helsinki.

Paulaharju, S. 1922. Lapin muisteluksia. Helsinki.

Paulson, I. 1958. Die primitiven Seelenvorstellungen der nordeurasischen Völker: Eine religionsethnographische und religionsphänomenologische Untersuchung. Stockholm.

Ränk, G. 1949. Kysymys Madderakan ja hänen tyttäriensä alkuperästä. Kalevalaseuran vuosikirja. Helsinki.

Sangi, V. M. 1985. Legendy i mify Severa. Biblioteka literatur narodnostei Severa i Dal'nego Vostoka. Moskva 
Sergeieva, E. 1994. Kuolansaamelaisten folkloresta - peuramies. Johdatus saamentutkimukseen. Tietolipas, 131. Helsinki, pp. 163170

Shchekoldin, K. 1890. Loparskie skazki, legendy i skazania, zapisannye v Pazreckom pogoste, pogranichnom s Norvegiei. Zhivaia starina. Vyp. 2, pp. 158-168.

Sienkiewicz-Gudkova, V. 1960. Ustinja Pavlovna Tarunova lapi muinasjutte. Emakeele Seltsi aastaraamat, 6 Tallinn, pp. 210-219.

Sokolova, Z. P. 1983. Social'naia organizacia hantov $i$ mansi $v$ XVIII-XIX vv.: Problemy fratri i roda. Moskva.

Szabò, L. 1967. Kolalappische Volksdichtung (Texte aus den Dialekten in Kildin und Ter). Abhandlungen der Akademie der Wissenschaften in Göttingen, Philologisch-historische Klasse. Dritte Folge, N 68. Göttingen.

Tjarnoluski, V. V. 1993. Den vilda renen i myt och rit. Jokkmokk.

Tradicionnoe mirovozzrenie tiurkov Iuzhnoi Sibiri: Prostranstvo i vremia. Veshtshnyi mir. Novosibirsk, 1988.

Tradicionnoe mirovozzrenie tiurkov Iuzhnoi Sibiri: Znak i ritual. Novosibirsk 1990.

Turunen, A. 1981. Kalevalan sanat ja niiden taustat. Helsinki.

Voskoboinikov, M. G., \& Menovshchikov, G. A. 1959.Skazki narodov Severa. Moskva-Leningrad.

Zaicev, B. 1927. "Utochka”: Obriad loparskoi svad'by. KareloMurmanski krai, 9, pp. 21-23. 